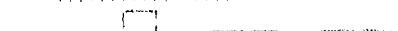

\title{
THE THERMAL DECOMPOSITION OF METHANE IN A TUBULAR REACTOR
}

\author{
ATSUSHI KOBAYASHI AND MEYER STEINBERG
}

\section{JANUARY 1992}

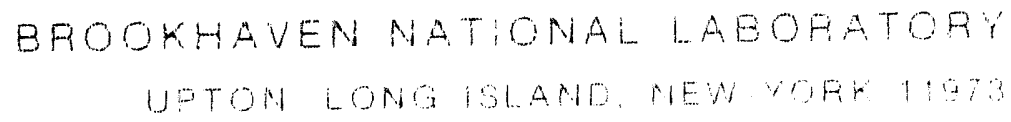




\section{DISCLAIMER}

This report was prepared as an account of work sponsored by the United States Government. Neither the United States nor the United States Department of Energy, nor any of their employees, nor any of their contractors, subcontractors, or their employees, makes any warranty, express or implied, or assurnes any legal liability or responsibility for the accuracy, completeness, or usefulness of any information, apparatus, product or process disclosed, or represents that its use would not infringe privately owned rights. 


\title{
THE THERMAL DECOMPOSITION OF METHANE IN A TUBULAR REACTOR
}

\author{
Atsushi Kobayashi and Meyer Steinberg \\ Brookhaven National Laboratory \\ Upton, NY 11973
}

January 1992

\section{DISCLAIMER}

\begin{abstract}
This report was prepared as an account of work sponsored by an agency of the Unized States Gcvernment. Neither the United States Government nor any agency thereof, nor any of their employees, makes any warranty, express or implied, or assumes any legal liability or responsibility for the accuracy, completeness, or usefulness of any information, apparatus, product, or process disclosed, or represents that its use would not infringe privately owned rights. Reference herein to any specific commercial product, process, or service by trade name, trademark. manufacturer, or otherwise does not necessarily constitute or imply its endorsement, recommendation, or favoring by the United States Government or any agency thereof. The views and opinions of authors expressed herein do not necessarily state or reflect those of the United States Government nr any agency thereof.
\end{abstract}

UNDER CONTRACT TO THE U.S. ENVIRONMENTAL PROTECTION AGENCY OFFICE OF RESEARCH AND DEVELOPMENT RESEARCH TRIANGLE PARK, NC 27711 


\title{
THE THERMAL DECOMPOSITION OF METHANE \\ IN A TUBUIJAR REACTOR
}

\author{
BY \\ Atsushi Kobayashi and Meyer Steinberg \\ Brookhaven National Laboratory \\ Upton, New York, 11973
}

Abstract

The reaction rate of methane decomposition using a tubular reactor having a 1 inch inside diameter with an 8 foot long heated zone was investigated in the temperature range of 700 to $900 \mathrm{C}$ with pressures rangina from 28.2 to $56.1 \mathrm{~atm}$. Represinting the rate by a conventional model, $-\mathrm{dC}_{\mathrm{CH} 4} / \mathrm{dt}=\mathrm{kI} \mathrm{C}_{\mathrm{CH} 4}-\mathrm{k} 2 \mathrm{C}_{\mathrm{H} 2}{ }^{2}$, the rate constant kI for methane decomposition was determined. The activation energy, $31.3 \mathrm{kcal} / \mathrm{mol}$, calculated by an Arrhenius plot was lower than for previously published results for methane decomposition. This result indicates that submicron particles found in the reactor adhere to the inside of the reactor and these submicron high surface area carbon particles tend to catalyze the methane decomposition. The rate constant has been found to be approximately constant at $900 \mathrm{C}$ with pressure range cited above. The rate of methane decomposition increases with methane partial pressure in first-order. The rate of the methane decomposition is favored by higher temperatures and pressures while the thermochemical equilibrium of methane decomposition is favored by lower pressures. 


\section{Introauction}

The Hydrocarb Process(1) consists of the two main reactions; (I)hydrogasification of the carboneous feedstock to produce a methane-rich gas and (2) the thermal decomposition of methane to produce carbon black and a hydrogen-rich gas. The section on methane decomposition is especially important in order to maintain high efficiency in the process. A key element in the process is that the hydrogen-rich gas produced in the methane decomposition reactor is recycled to the hydrogasification reactor as the reactant gas. Furthermore, the product sarbon black is produced in the methane decomposition section.

This work was performed in order to investigate the phenomena of methane decomposition and to obtain data on the kinetic rate of the reaction for the purpose of designing the methane decomposition reactor.

2. Chemical Equilibriurn

Since the methane decomposition is endothermic, the methane concentration decreases with increasing temperature. Due to the increase of volume during methane decomposition, the decomposition of methane is favored by decreasing pressure.

$\mathrm{CH}_{4}=\mathrm{C}+2 \mathrm{H}_{2}-17.9 \mathrm{kcal} / \mathrm{mol}$

Figure 1 shows the equilibrium data of the methane at temperature from 600 to $1200 \mathrm{C}$ and at pressures of $25,30,40$, and 50 atm. These data are calculated from the following Gibbs Free Energy and equilibrium constant. 


$$
\begin{aligned}
& R \quad T \ln k_{x}=-d G \\
& \mathrm{~K}_{\mathrm{x}}=\mathrm{x}_{\mathrm{H} 2}^{2} / \mathrm{x}_{\mathrm{CH} 4}
\end{aligned}
$$

where $\mathrm{X}$ is the mol fraction of each gaseous component, and

$\mathrm{K}_{\text {Where }}=(\mathrm{pp} \mathrm{H2})^{2} / \mathrm{pp} \mathrm{CH} 4$

Where pp is the partial pressure of each component

\section{Experimental}

Figure 2 shows the schematic flow sheet of the experimental equipment which mainly consists of a tubular reactor, a carbon trap, a gas-chromatograph and gas meter. Methane enters the system through a remotely controlled regulator located next to the methane cylinders which keeps the pressure approximately constant at selected pressure of $28.2,41.8$ or 56.1 atm in the system. Methane then flows through a preheater and enters into the reactor which consists of a 1 inch inside diameter by $1 / 4$ inch wall Inconel 617 tube. The total length of the reactor tube is 11 feet of which the first 8 feet is externally heated and selectively maintained at constant experimental temperatures $c: 700,800$ and $900 \mathrm{C}$ by clamshell electric heaters. Methane is decomposed into carbon and hydrogen in the heated reactor and the effluent gas flows through the carbon trap connected at the bottom of the reactor, where the carbon generated by the reaction is separated. Gas is sampled before and after the reactor through sampling lines to an on-line gas-chromatograph. The concentrations of $\mathrm{CH} 4, \mathrm{CO}$, and $\mathrm{CO} 2$ in the gas are measured using the thermal conductivity detector. The flow rate of exit gas is controlled in the range between 10 and 150 liters/min. by a flow valve located after the reactor. The exit gas 
flows through the gas meter where the flow rate is measured and the gas is finally vented to the atmosphere.

\section{Experimental Result and Discussion}

Table 1 shows the results of the data for the experimental runs to measure the conversion of methane into hydrogen and carbon at 700,800 , and $900 \mathrm{C}$ and at 56.1, 41.8 and 28.2 atm. Figure 3 shows the relationship between the methane concentrations in exit gas and residence time in the reactor under these conditions. The residence time of the methane gas in the reactor is given by the inlet gas velocity. The concentration of the methane decreases with increasing temperature and residence time. At both 700 and $800 \mathrm{C}$ and at 56.1 atm the concentration of methane decreases less with residence time than that at $900 \mathrm{C}$ and $56.1 \mathrm{~atm}$. Under the latter conditions, the concentration of methane decreases dramatically with residence time and appears to be approaching equilibrium conditions. The concentration of methane at a residence time of 103 seconds was 48.1 vol\%, and in this case the equilibrium concentration of the methane is 39.6 vol\%.

The equilibrium data at the lower temperatures of 700 and 800 $C$ and at 56.1 atm are 54.3 and 69.3 vol\% respectively and higher than that at $900 \mathrm{c}$. Taking these conditions into account and considering the curves of methane decomposition in Figure 3 , the rate of methane decomposition in the lower temperature range seems to be much smaller than that at the higher temperature of $900 \mathrm{C}$.

Generally the equation for the rate of decomposition of methane 
is derived as follows;

$\mathrm{CH}_{4} \underset{\mathrm{k} 2}{\stackrel{\mathrm{k}}{2}} \mathrm{C}+2 \mathrm{H}_{2}$

where $\mathrm{kl}$ is the rate constant of methane decomposition, and $\mathrm{k} 2$ is the rate constant of methane formation

The rate equation for this reversible reaction can be written as follows ;

$$
\begin{aligned}
& \begin{aligned}
-\mathrm{r}_{\mathrm{CH} 4} & =-\mathrm{dC}_{\mathrm{CH} 4} / \mathrm{dt}=\mathrm{k} 1 \mathrm{C}_{\mathrm{CH} 4}-\mathrm{k} 2 \mathrm{C}_{\mathrm{H} 2}{ }^{2} \\
& =\mathrm{kl} \mathrm{C}_{\mathrm{CH} 4}\left(1-1 / \mathrm{Ke} \times \mathrm{C}_{\mathrm{H} 2}{ }^{2} / \mathrm{C}_{\mathrm{CH} 4}\right)
\end{aligned} \\
& \text { where } \mathrm{C}_{\mathrm{CH} 4}, \mathrm{C}_{\mathrm{H} 2} \text { are the molar concentrations of } \mathrm{CH} 4 \text { and } \mathrm{H} 2 \\
& \text { respectively }
\end{aligned}
$$

The above differential equation for methane decomposition in the tubular reactor is solved for the condition of $\mathrm{C}_{\mathrm{H} 2 \mathrm{O}}=0$ (initial concentration of hydrogen is 0 ), for inlet methane concentratrion $\mathrm{C}_{\mathrm{CH} 40}$, exit methane concentration $\mathrm{C}_{\mathrm{CH} 4}$, and equilibrium concentration of methane $\mathrm{C}_{\mathrm{CH} L \mathrm{E}}$. Figure 4 shows a model of the tubular reactor and the derivation of the following rate equation.

$$
\begin{aligned}
& \mathrm{kl} \times t=\frac{\mathrm{C}_{\mathrm{CH} 4 \mathrm{O}}-\mathrm{C}_{\mathrm{CH} 4 \mathrm{E}}}{\mathrm{C}_{\mathrm{CH} 4 \mathrm{O}}+\mathrm{C}_{\mathrm{CH} 4 \mathrm{E}}} \text { in } \frac{\mathrm{C}_{\mathrm{CH} 40^{2}}-\mathrm{C}_{\mathrm{CH} 4} \times \mathrm{C}_{\mathrm{CH} 4 \mathrm{E}}}{\mathrm{C}_{\mathrm{CH} 4 \mathrm{O}} \times\left(\mathrm{C}_{\mathrm{CH} 4}-\mathrm{C}_{\mathrm{CH} \text { }}\right)} \\
& \text { where } t \text { is the residence time }
\end{aligned}
$$

Table 2 shows the calculated data of inlet, outlet and equilibrium concentrations of methane, inlet flow rate, and $k 1 \times t$ values. Figure 5 shows the relationship between $x I \times t$ value versus residence time at 700,800 , and $900 \mathrm{C}$ and at $56.1 \mathrm{~atm}$. Each slope in the Figure 5 indicates a rate constant $k 1$ of the methane decomposition at each temperature. Table 3 represents the $k l$ value at these conditions. 
Table 3 Rate constants at 56.1 atm

\begin{tabular}{|cl|cc|}
\hline \multicolumn{2}{|c|}{ Temperature } & \multicolumn{2}{|c|}{$\mathrm{kl}$ value } \\
\hline 700 & $\mathrm{C}$ & $5.758 \mathrm{E}-4$ & $1 / \mathrm{sec}$ \\
800 & $\mathrm{C}$ & $1.753 \mathrm{E}-3$ & $1 / \mathrm{sec}$ \\
900 & $\mathrm{C}$ & $9.306 \mathrm{E}-3$ & $1 / \mathrm{sec}$ \\
\hline
\end{tabular}

In Figure 6 , the rate constants, $k 1$, for methane decomposition are plotted versus recipical temperature. From this Arrhenius plot an activation energy for methane decomposition and the rate constant $\mathrm{kl}$ are calculated as follows;

$$
\begin{array}{lll}
E=31.3 & & \mathrm{kcal} / \mathrm{mol} \\
\mathrm{kI}=5.4 \times 10^{3} \text { exp }(-\mathrm{E} / \mathrm{RT}) & 1 / \mathrm{sec}
\end{array}
$$

The activation energy appears to indicate a diffusion controlled process which usually has values up to about $30 \mathrm{kcal} / \mathrm{mol}$ as opposed to a chemical reaction controlled process which has much higher activation energies ranging above $50 \mathrm{kcal} / \mathrm{mol}$. From the Iimited methane decomposition data in the literatures $(2,3,4,5$, and 6$)$, the homogeneous activation energy for methane decomposition is determined to be $65 \mathrm{kcal} / \mathrm{mol}$. The data gathered in these experiments appears to be influenced by a heterogeneous effect of surfaces. During our experiments some of the carbon formed from methane decomposition adhered to the walls $r$ the Inconel high alloy steel of the tubular reactor. In fact, at the end of several extended runs, it was found that the carbon plugged the tube to the extent that it restricted the gas flow. Thus, the fine submicron carbon particles could tend to catalyze the themal decomposition of the methane. References 7 and 8 clearly indicate that different 
materials increase the rate of the mathane decomposition in the order of iron oxide, alumina, graphite, and quartz. In the tubular reactor the small submicron particle size of the carbon presents a very large surface area on which methane can decompose and thus a lower activation energy for decomposition results.

The influence of the total pressure in this system on the rate constant of the methane decomposition was investigated because the Hydrocarb Process is being operated under pressure and it is important to determine the influence of the total pressure on the reaction rate. Figure 7 shows the relationship between the $k 1 \times t$ value and residence time at $28.2,41.8$, and 56.1 atm at $900 \mathrm{C}$. The slopes in Figure 7 represent the rate constants $k 1$ at their respective conditions. These values are calculated and listed in Table 4 .

Table 4 Rate constants at 900 degree centigrade

\begin{tabular}{|l|ll|}
\hline Pressure & k1 value \\
\hline 28.2 atm & $1.066 \mathrm{E}-2$ & $1 / \mathrm{sec}$ \\
41.8 atm & $1.380 \mathrm{E}-2$ & $1 / \mathrm{sec}$ \\
56.1 atm & $9.306 \mathrm{E}-3$ & $1 / \mathrm{sec}$ \\
\hline
\end{tabular}

average rate constant $1.126 \mathrm{E}-2 \quad 1 / \mathrm{sec}$

Although there is not enough data to establish a relationship with pressure, the rate constant appears to be aproximately constant with pressure. The variation in the rate constant with pressure is probably within the deviation in the experimental measurements for this type of equipment. Some other studies to obtain the rate data of carbon formation from methane on silicate substrate indicate that the rate increased in first-order with pressure up to 15 
$\operatorname{atm}^{(2)}$. The rate equation(6) model led in this paper indicates that since the methane molar concentration is first-order in pressure, tine result that the ra:e constant is constant and independent of pressure is in accord with other published results; and the rate of the methane decomposition indeed increases with partial methane pressure approximately in first-order. The thermochemical equilibrium for methane decomposition is favored by lower pressures, but as our results indicate, the rate is favored by higher pressure.

\section{Conclusion}

The influence of the temperature and total pressure on the rate of the methane decomposition has been determined by using a tubular reactor assembly. The following results and conclusions were obtained.

(1) A model for methane decomposition was developed, which resulted in the following rate equation;

$$
\begin{aligned}
-r_{\mathrm{CH} 4} & =-\mathrm{dC}_{\mathrm{CH} 4} / \mathrm{dt}=\mathrm{k} 1 \mathrm{C}_{\mathrm{CH} 4}-\mathrm{k} 2 \mathrm{C}_{\mathrm{H} 2}{ }^{2} \\
& =\mathrm{kl} \mathrm{C}_{\mathrm{CH} 4}\left(I-1 / \mathrm{Ke} \times \mathrm{C}_{\mathrm{H} 2}{ }^{2} / \mathrm{C}_{\mathrm{CH} 4}\right)
\end{aligned}
$$

$k 1$ value was calculated as follows;

$$
k 1 \times t=\frac{C_{C H 40}-C_{C H 4 E}}{C_{C H 40}+C_{C H 4 E}} \text { In } \frac{C_{C H 40}{ }^{2}-C_{C H 4} \times C_{C H 4 E}}{C_{C H 40} \times\left(C_{C H 4}-C_{C H 4 E}\right)}
$$

An Arrhenius plot of the $k 1$ values resulted in the following rate constant equation.

$$
k 1=5.4 \times 10^{3} \exp (-31.3 \mathrm{kcal} / \mathrm{RT}) \quad 1 / \mathrm{sec}
$$


The activation energy appears to indicate a diffusion controlled process most likely influenced by the high surface area of the submicron carbon particles deposited in the reaction zone.

(2) Although a definitive influence of the total pressure on the rate constant of the methane decomposition could not be clearly determined, at $900 \mathrm{C}$, within experimental error, the rate constant appears to be constant and independent of pressure in the range of 28.1 to $56.1 \mathrm{~atm}$. Taking into account the rate equation modelled in this paper, the rate of decomposition is influenced by the methane partial pressure to

the first-order. Taking into account these results together with literature data, the conclusion is reached that although the thermochemical equilibrium decomposition of methane is favored by lower pressure, the rate of methane decomposition is favored by higher pressure.

Work performed in-part by US DOE 


\section{Reference}

1) M. Steinberg, "Biomass and Hydrocarb Technology for Removal of Atomospheric $\mathrm{CO}^{\prime \prime}$, BNL 44410, Brookhaven National Laboratory, Upton, NY, (March 1990)

2) E. F. Aref'eva, et al., Khimiya Tveraogo Topliviva 11, No. 1, $1129-35(1977)$

3) P. A. Tenser, et al., EF.11, No. 5 113-16(1977)

4) Kurt Hedden et al., Fourth Carbon Conference, August 22,1961

5) K.I. Makaror and V.K. Pechic: "Kinetica of Methane Thermal Decomposition on the Carbon Surface in Transient Regime", vol 7 pp. 278-285 (1969), Pergamon Press.

6) Margaret H. Back and Robert A. Back; "Thermal Decompositiopn and Reaction of Methane", Industrial Pyrolysis (1983)

7) N. Z. Muradov "How to Produce Hydrogen from Fossil Fuels without $\mathrm{CO} 2$ Emissions"; Informal Reprot, Insitute of Petrochemical Processes, Azerbaijan, SSR, Baku, U.S.S.R.

8) Jack B. Pohlenz, et al.," Method for Hydrogen Production by Catalytic Decomposition of a Gaseous Hydrocarb Stream"; United States Patent 3,284,161, Nov. 8, 196 $i$ and "Process Hydrogen from Hydrocarbons"; Chem. Eng. 69, pp90-91, 1962 


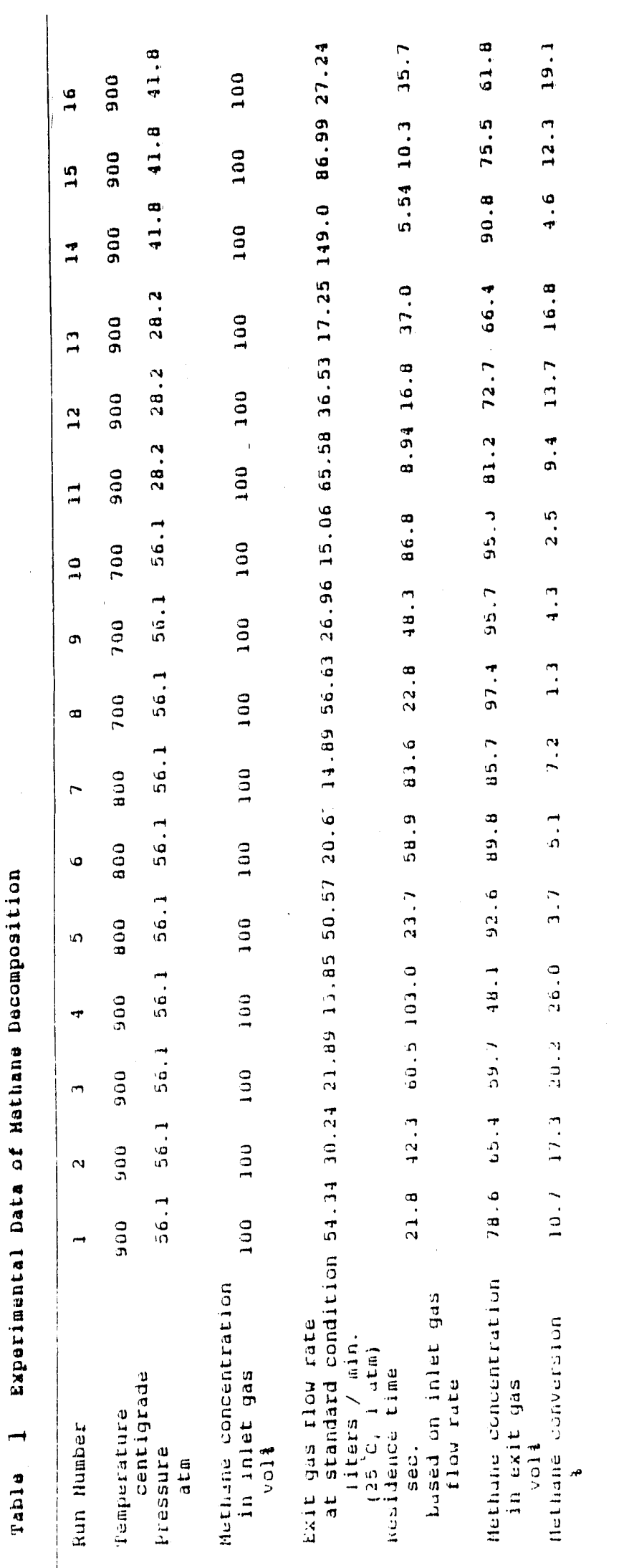




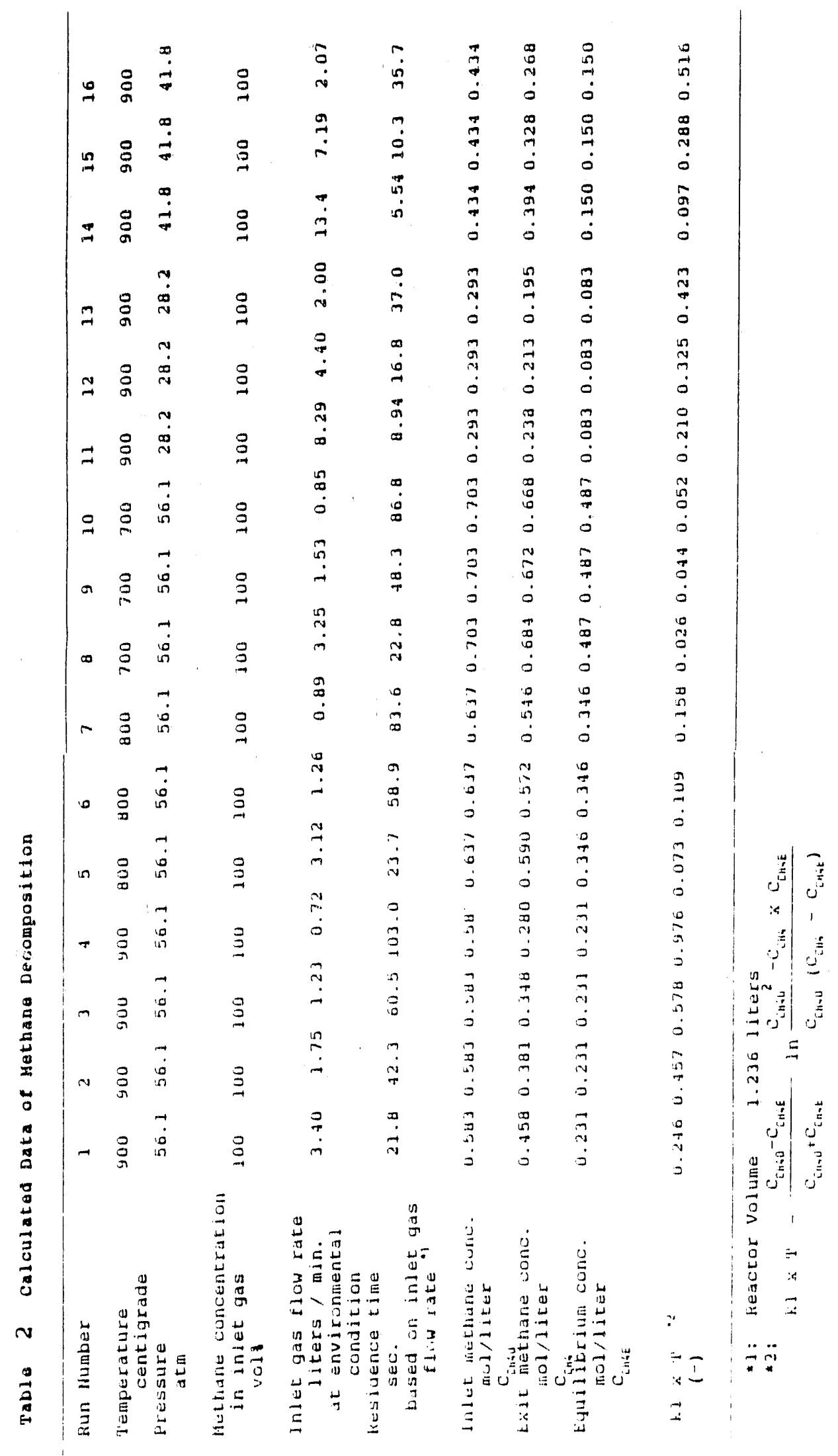



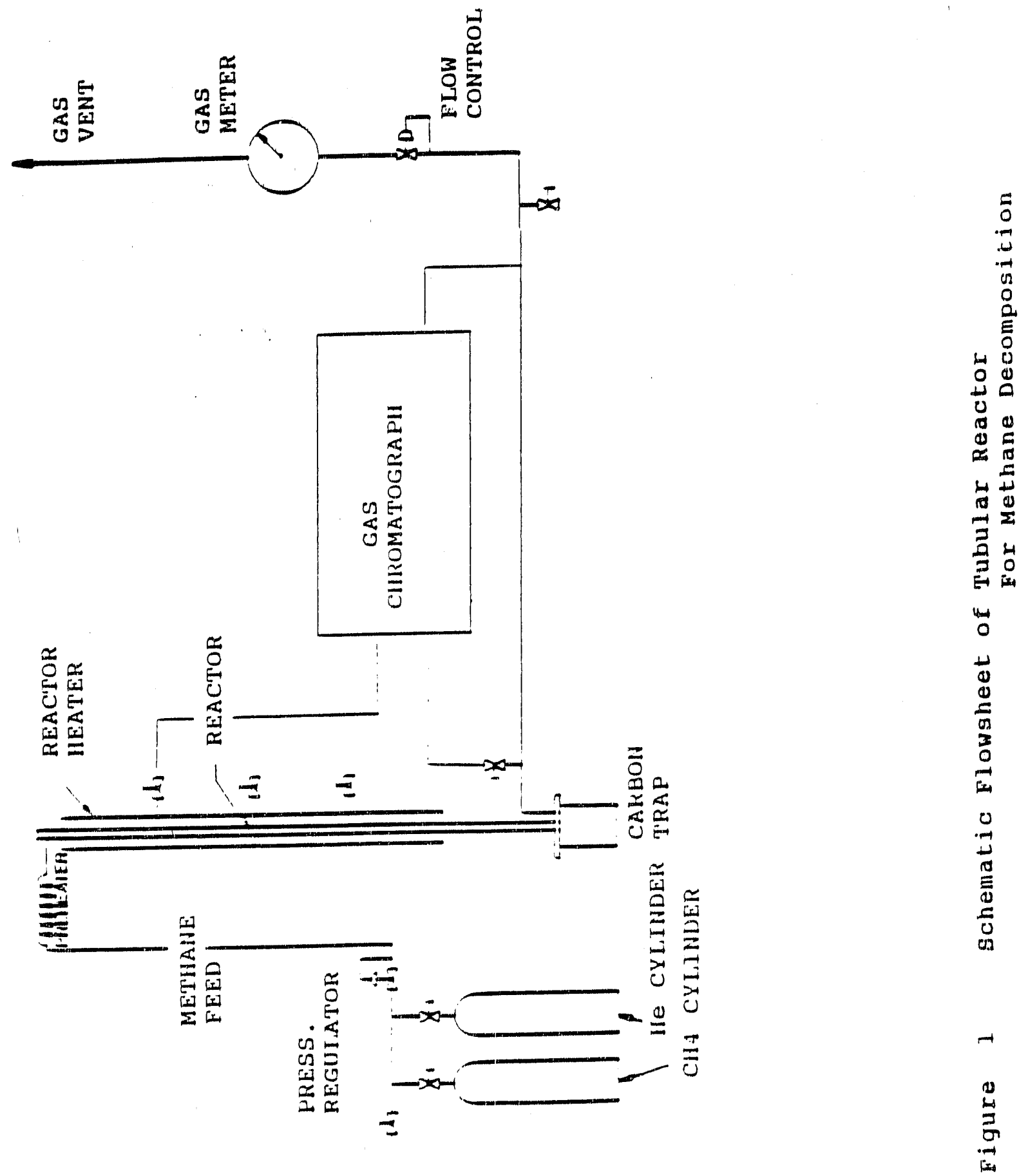


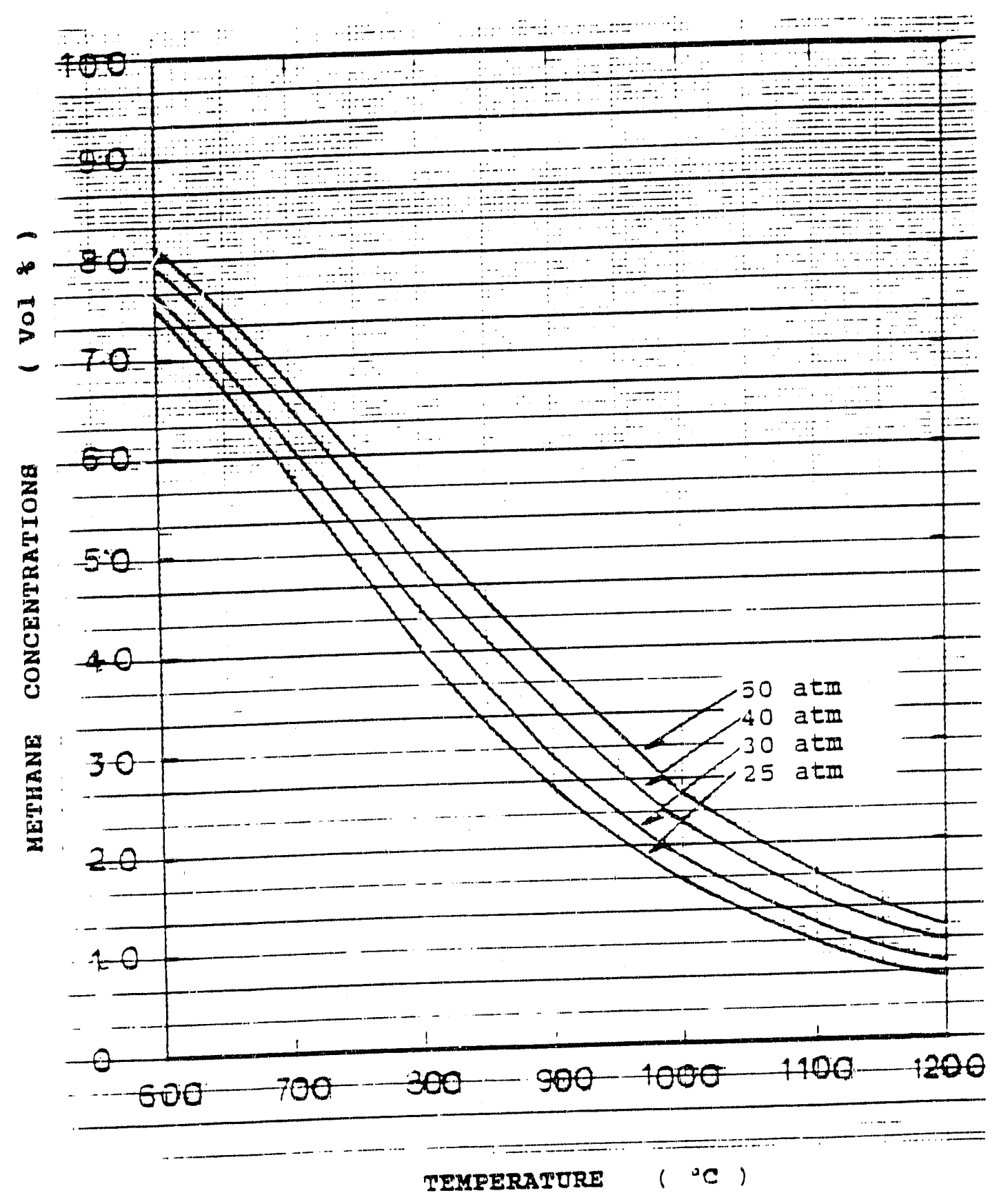

Fifgre 2 Equilibrium Daca of Methane 


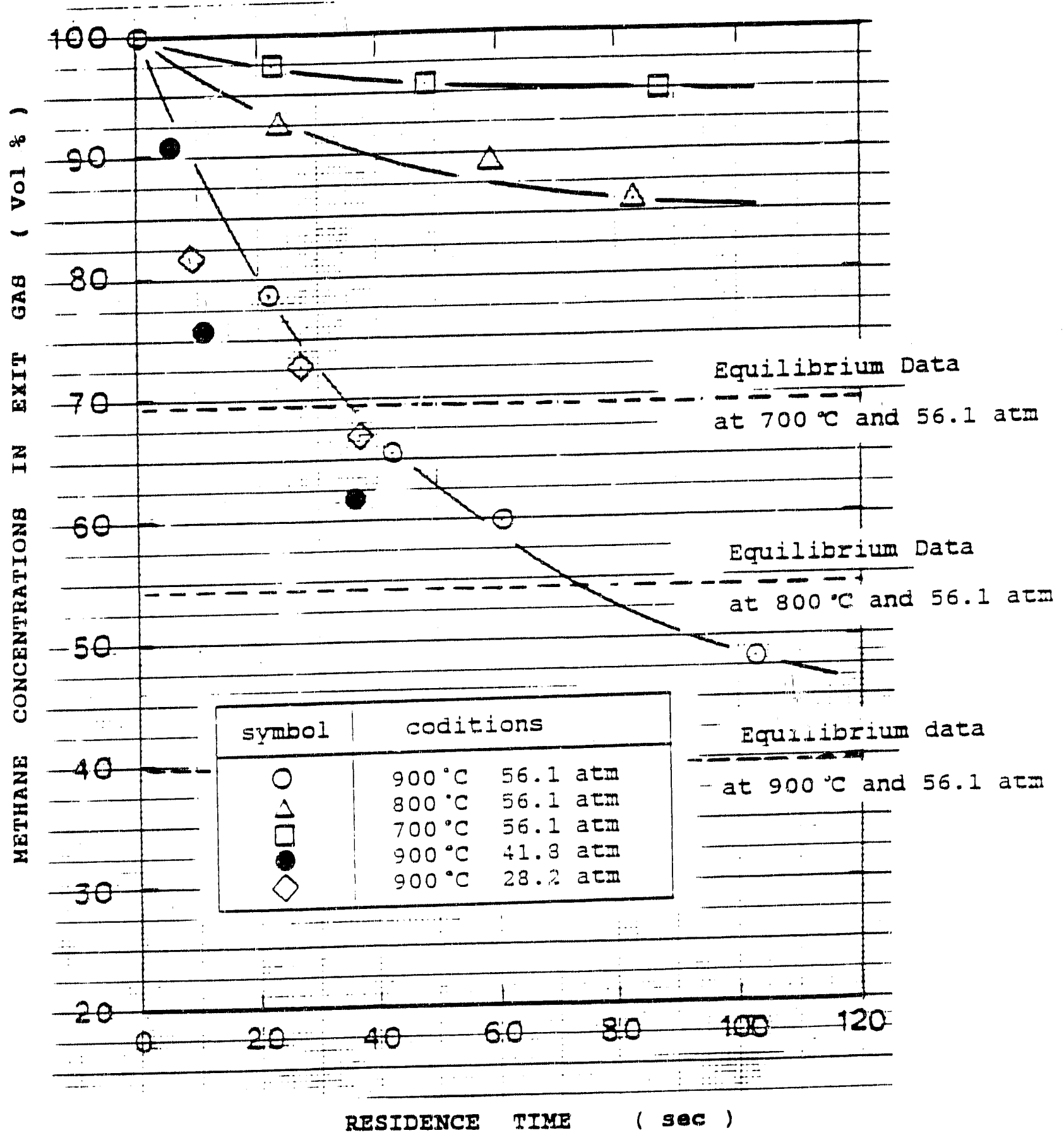

Figure 3 Metrane concentrations vs. residence time 


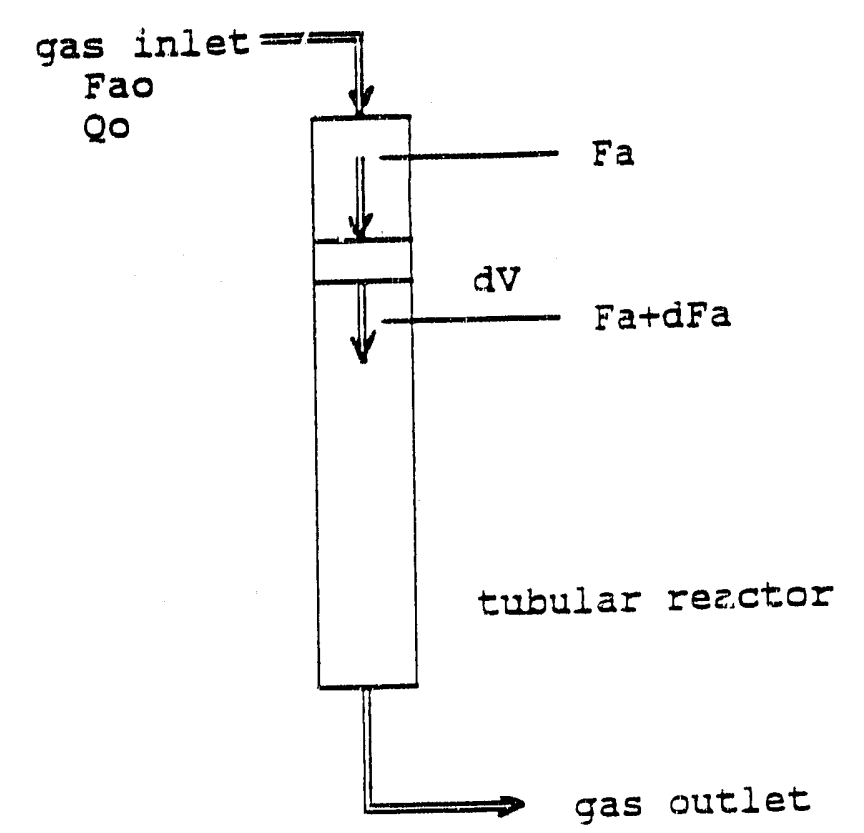

\section{Trubular Raactor Model}

Mass Balance of A component

$$
\begin{aligned}
& F a=F a+d F a+\left(-r_{A}\right) \times d V \\
& -d F a=\left(-r_{A}\right) \times d V \\
& F a=F a o \times\left(1-x_{A}\right) \\
& d V / F a O=d x_{A} /\left(-r_{A}\right) \\
& F a o=Q 0 \times C a O \\
& d V / Q 0=\text { Cao } \times d x_{A} /\left(-r_{A}\right) \\
& d V / Q 0=d t \\
& C a=\text { Cao } \times\left(1-x_{A}\right) \\
& -d C a / d t=-r_{A}
\end{aligned}
$$

Fa :molar velocity (mol/sec)

$Q$ :volume velocity (liters/sec)

$\mathrm{Ca}$ : concentrarion of A component (mol/liter)

$x_{1}$ : degree of conversion of A component (-)

subscript o :iritial conditionh

\section{Reaction Rate Model}

$$
\begin{aligned}
& \mathrm{CH}_{4} \frac{\mathrm{kl}}{\mathrm{k} 2} \mathrm{C}+2 \mathrm{H}_{2} \\
& -r_{\mathrm{CH} 4}=-d C_{\mathrm{CH} 4} / d t=k 1 \times C_{\mathrm{OH} 4}-k 2 \times C_{\mathrm{H} 2}^{2}
\end{aligned}
$$




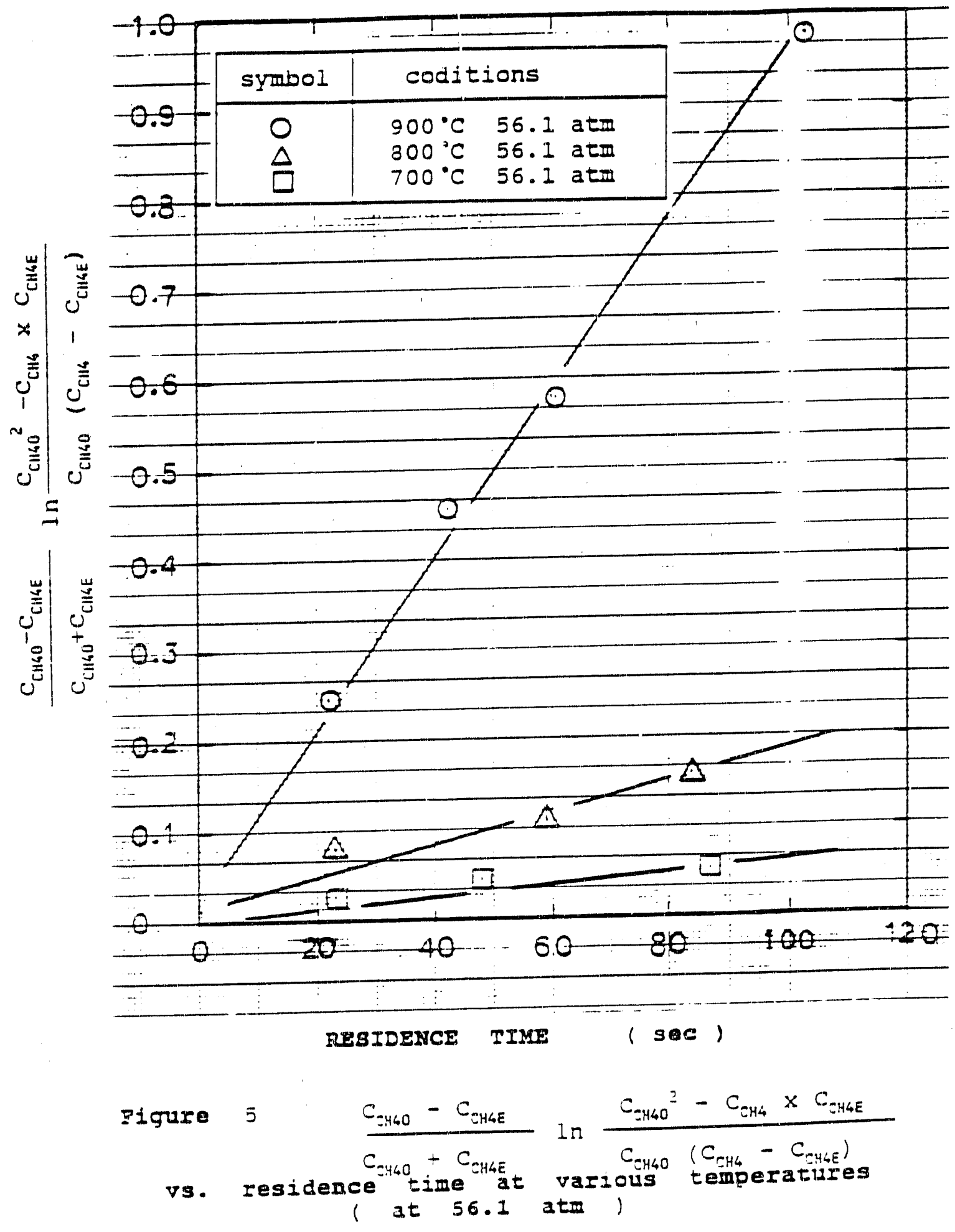




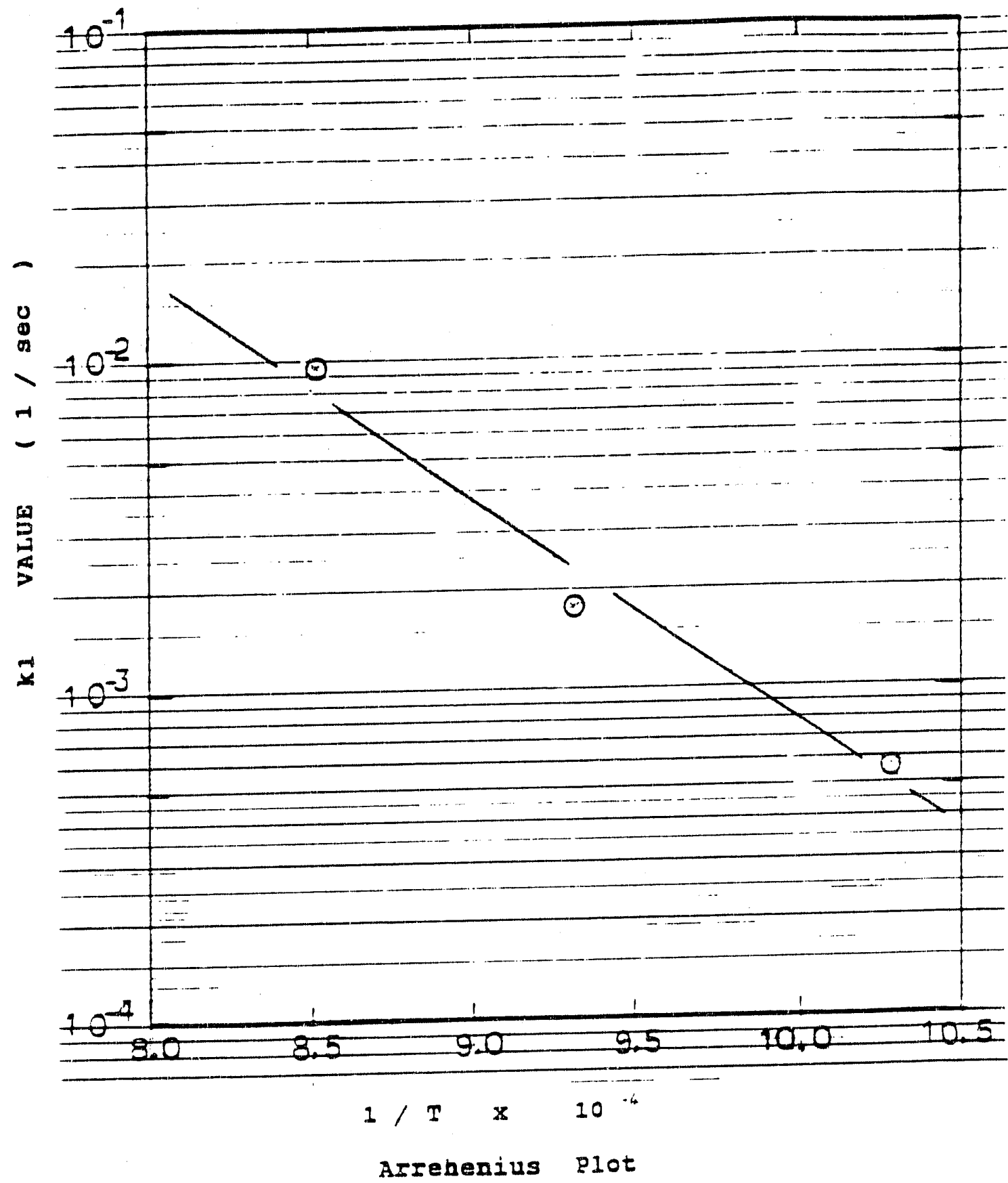

Figure 6 Rate constant of Metbane Decomposition
recipical temperature ( at 56.1 atm)

vs. 


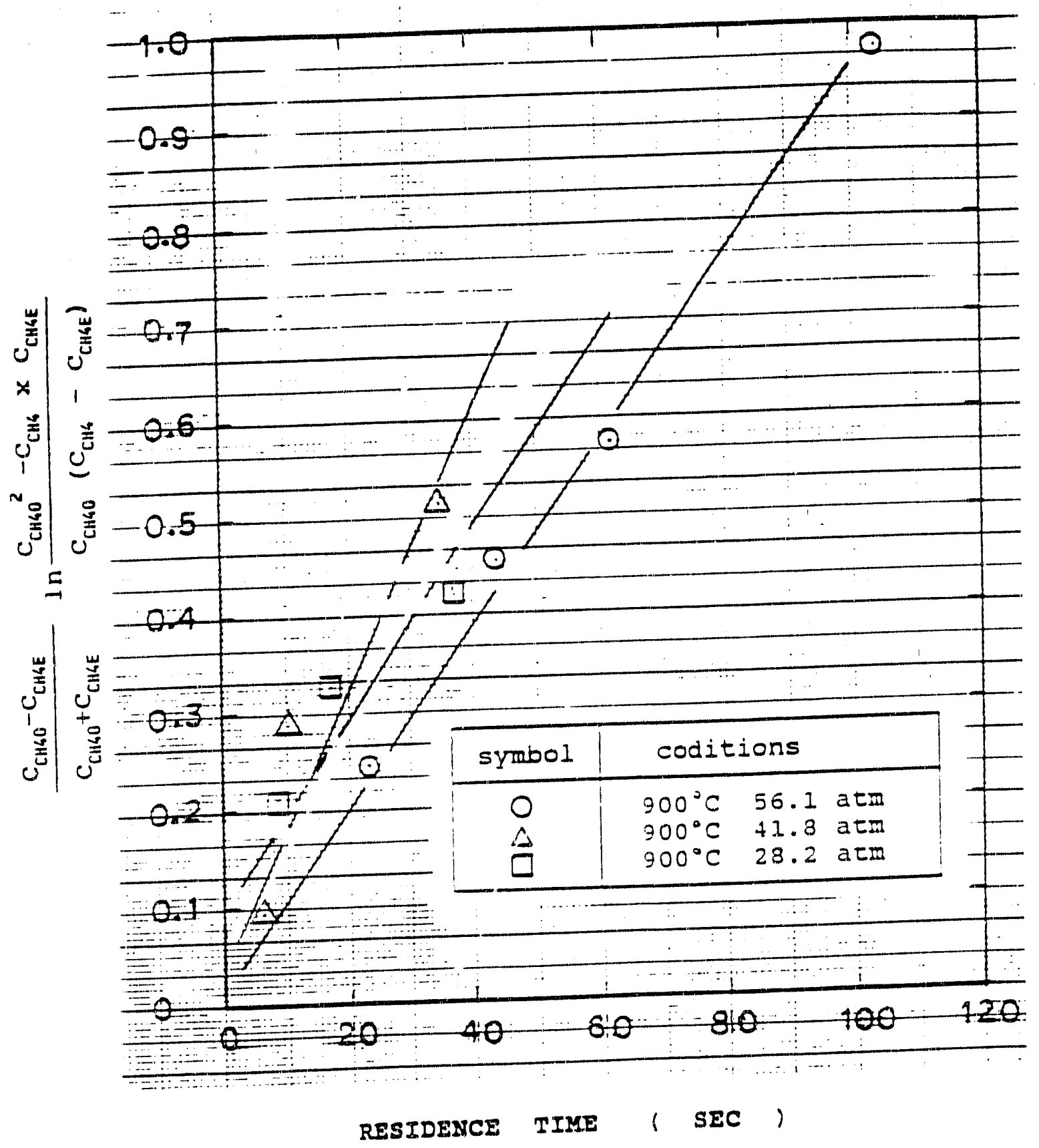

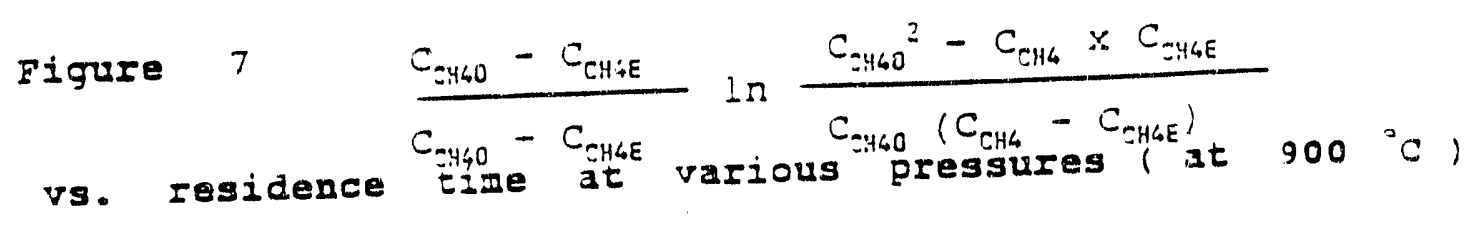




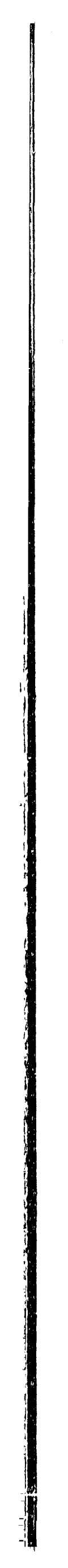

